\title{
Balıkesir Şehrinde Su Tüketimi: Coğrafi Bir Yaklașım
}

\section{Water consumption in Ballkesir city: A geographical approach}

\section{Alpaslan Aliağaoğlu*a, Güldane Mirioğlu ${ }^{b}$}

\begin{tabular}{l} 
Makale Bilgisi \\
\hline DOI: \\
10.33688/aucbd. 593693 \\
\hline Makale Geçmişi: \\
Geliş: 18.07.2019 \\
Kabul: 03.09.2019 \\
\hline Anahtar Kelimeler: \\
Balıkesir Şehri \\
Su \\
Su Tüketimi \\
Mekânsal Dağılım
\end{tabular}

\section{Article Info}

DOI:

10.33688/aucbd. 593693

Article History:

Received: 18.07.2019

Accepted: 03.09.2019

Keywords:

Balıkesir City

Water

Water Consumption

Spatial Distribution
$\ddot{O}_{z}$

Su az bulunan bir doğal kaynaktır. Şehirsel yaşanabilirlik diğer nedenler yanında suyun varlığına bağlıdır. Şehirler farklı ölçekte su tüketen yerleşmelerdir. Şehirsel mekânda su tüketimi farklılaşmaktadır. Bu çalışmada su tüketiminin coğrafi dă̆llışı Balıkesir şehri için ele alınmaktadır. Veriler Balıkesir Büyükşehir Belediyesi ile ilçe belediyelerinden alınmıştır. Çalışmada Balıkesir'in şehirsel mahallelerinde, mahallelerin nüfus miktarı, iş yeri sayısl, gelir düzeyi, eğitim düzeyi ve kuyu suyu aboneliği değişkenlerinin su tüketimi ile ilişkisi korelasyon analizi ile incelenmiştir. Sonuçta görülmektedir ki nüfus miktarl, işyeri sayısı, gelir düzeyi, eğitim düzeyi ve kuyu suyu aboneliği ile su tüketimi arasında anlamlı bir ilişki vardır. İsyeri sayısı özellikle kişi başına su tüketimini etkileyen önemli bir faktördür. Kiși başına su tüketimi merkezi iş alanında bu nedenle artmaktadır.

\begin{abstract}
Water is a rare natural resource. Urban viability depends on the presence of water, among other reasons. Cities are settlements that consume water at different scales. Water consumption varies in urban areas. In this study, geographical distribution of water consumption is discussed for Ballkesir city. Data were taken from Ballkesir Metropolitan Municipality and district municipalities. In this study, the relationship between the variables of population, number of workplaces, income level, education level and well water subscription with water consumption in urban neighborhoods of Ballkesir was investigated by correlation analysis. As a result, it can be seen that there is a significiant relation between water consumption and the amount of population, number of establishments, income level, education level and well water subscription. The number of establishments is an important factor affecting water consumption per capita. Per capita water consumption is therefore increasing in the central business distrcit.
\end{abstract}

\footnotetext{
*Sorumlu Yazar/Corresponding Author: . Alpaslan Aliağaoğlu, alpaslan38ster@gmail.com

aBalıkesir Üniversitesi, Fen-Edebiyat Fakültesi, Coğrafya Bölümü, Balıkesir, Türkiye, http://orcid.org/0000-0002-61983878

bैBalıkesir Üniversitesi, Fen-Edebiyat Fakültesi, Coğrafya Bölümü, Balıkesir, Türkiye, http://orcid.org/0000-0003-31915935
} 


\section{Giriș}

Su yeryüzünde bulunan temel kaynaklardan biridir. Yeryüzünün büyük bir kısmı (2/3'ü) sularla kaplıdır. Ancak su kaynakları eşit bir şekilde dağılmadığı gibi mevcut suyun çok az bir kısmı kullanılabilmektedir. Su insan için olduğu kadar, doğal yaşam için de olmazsa olmaz bir nesnedir. Su insan için biyolojik bir zorunluluktur. İnsan vücudunun büyük bir kısmı sudan oluştuğu gibi su sağlıklı bir hayat için gereklidir. İnsan metabolizması çeşitli nedenlerle suya ihtiyaç duymaktadır. Vücudun kimyasal reaksiyonunun sağlanmasından, besin ve artık maddelerin gerekli yerlere taşınması suya bağlıdır. İnsanlar ancak bir hafta susuz yaşayabilmektedir. Şehirsel hayatın kalitesi ve çeşitli varlıklar için fizyolojik gereklilik ve yaşam ortamı olan su farklı amaçlar için kullanılmaktadır. Yerleşmeler suyu, içme ve kullanma suyu, şehirsel temizlik, doğal hayatın devamı, tarımsal sulama, sanayi üretimi (kullanma ve soğutma suyu ihtiyacı), turizm faaliyetleri, balıkçılık gibi farklı şekillerde tüketmektedirler. Su tüketimi, nüfusun artışı, iklimin değişimi, sanayi ve teknolojide yaşanan gelişmeler ve yaşam biçimlerinin değişimi gibi nedenlerle giderek artmaktadır.

İnsan su ilişkisi çok eskilere dayanmaktadır. Bu bağlamda tarımsal üretimin başlaması, yerleşik hayata geçiş ve şehirlerin ortaya çıkışı suya bağlıdır. Bu yüzden yerleşmeler özellikle şehirler su kaynakları ve akarsuların yakınında yer seçmişlerdir. Bu durum kurak ve yarı kurak alanlar için daha belirgindir. Su olmadan şehirsel hayat mümkün değildir. Çok sayıda işleve sahip şehirler çeşitli şekillerde suya ihtiyaç duyarlar. Su altyapısı şehirlerin kan damarı olma özelliğine sahiptirler. Görsel güzellikler, temizlik, fizyolojik ihtiyaçlar, kirli maddelerin uzaklaştırılması, sanayi ve enerji üretimi hep suyun varlığına bağlıdır. Ancak şehir su ilişkisi tek yönlü değildir. Şehirleşme, sanayileşme ve teknolojik gelişmelere birlikte suların (yeraltı suyu, akarsu, göl, deniz ve okyanuslar) kirlenmesine neden oldukları gibi su taşkınlarına da neden olabilirler.

Şehirler çok miktarda su tüketen yerleşmelerdir. Bu durumun çeşitli nedenleri vardır. Nüfus miktarı, nüfusun gelir seviyesi, iklim ve şehirde yer alan diğer etkinliklere bağlı olarak su tüketimi değişsebilmektedir. Su tüketimi şehirsel alanlarda da işlevsel özelliklere bağlı olarak farklılaşmaktadır. Konut alanlarının su ihtiyacı ile ticari işyerlerinin yaygınlık kazandığı yerlerin su ihtiyacı aynı değildir. Bu bağlamda işyerlerinin çeşidi de su tüketimini etkiler. Konut alanları da aynı ölçüde su tüketmezler. Bu durum nüfus miktarı, nüfusun satın alma gücü, hane halkı sayısı, su tüketim davranışları ve gelenekler gibi farklı nedenlerden kaynaklanmaktadır. Bu çalışmada su tüketiminin coğrafi dağılışı mahalle ölçeğinde Balıkesir şehri için ele alınmaktadır. Bu bağlamda yapılan çalışmaların azlığı ve yokluğu çalışmanın özgün yanıdır. Yine azalan bir kaynak olan suyun şehir içi tüketiminin coğrafi dağılışı ve bu dağılışı etkileyen nedenlerin bilinmesi, su kaynaklarının etkin kullanımında, şehirsel planlama ve karar verme sürecinde önemli katkı sağlayacaktır.

\section{2. İlgili Çalışmalar}

Yeryüzü suyla kaplı olmakla birlikte, mevcut suyun çok az bir kısmı (\%3) içilebilir niteliktedir. İçilebilir suyun ise \% l'ine erişilebilmektedir. Başka bir anlatımla, mevcut su miktarının $\%$ 0, 007'si içilebilmektedir (Ceylan, 2010). Yine su kaynakları dengeli dağılmış değildir. Bu yönüyle bakıldığında Türkiye su zengini bir ülke değildir. Türkiye $1555 \mathrm{~m}$ küp su kullanımıyla su azlığı çeken bir ülke konumundadır. Kişi başına yıllık tüketilen suyun 2000 m küpten fazla olması zenginliği, 
1000 m küpten az olması fakirliği ifade etmektedir (Akın ve Akın, 2007). Akın ve Akın (2007), suyun önemi, Türkiye'nin su potansiyeli, su havzaları ve su kirliliği konusunu ele almaktadır. Su kaynaklarının yönetimi önemlidir (Aksungur, Firidin ve SUMEA, 2008). Su azlığının yaşanması su tüketiminde dikkatli davranmayı gerektirmektedir. Ceylan, 2010, binalarda su tüketiminde tasarruf yöntemlerini ele almaktadır. Su tüketim davranışlarının bilinmesi de kullanımı etkilemektedir. Pehlivan vd. (2017), Malatya şehrinde gençlerin su tüketimine yönelik davranışlarını çalışma konusu yapmışlardır. Çalışmaya göre, kadınlar su tüketimi açısından daha olumlu davranışa sahiptirler. Spor etkinliğine katılımın bu davranışı olumlu etkilediği görülmektedir. Su kıtlığı yaşanacağı düşüncesi, su tüketimi davranış ve bilincini olumlu yönde etkilemektedir. Çalışmada aylık gelir, eğitim durumu ve aile yapısı tüketim davranışlarında önemli olmayan etkenlerdir. Gezer ve Erdem (2018), su stersi, su kıtlığı ve su tasarrufu farkındalığını çalışmışlardır. Kullanıcıların büyük bir çoğunluğu cinsiyet ve yaştan bağımsız olarak su kullanımında benzer özelliklere sahiptirler. Kadınlar, su stresi, kitlığı ve tasarrufu konusunda daha bilinçli durumdadır. Gelir seviyesinin artması da duyarlılıkta artışa neden olmaktadir.

Su ihtiyacı çeşitli kaynaklardan sağlanmaktadır. Bunlar çoğunlukla akarsular ve yeraltı sularıdır. Örnek olarak Erzurum şehrinin suyu, aynı adı taşıyan ovadan yeraltı su kaynakları vasıtasıyla sağlanırken, zamanla bu sularda nitrat oranının artması nedeniyle yeni kaynaklara ihtiyaç duyulmuştur. Palandöken barajı şehrin mevcut ve gelecekteki su ihtiyacını karşılama potansiyeline sahiptir. Bu suların kalitesi, arıtma işlemlerinden sonra artacaktır (Koday ve Kaya, 2012).

Karakuş (2014) Edirne ilinde bireylerin su tüketim tercihlerini etkileyen faktörleri ele aldı. Çalışmanın sonuçlarına göre, ambalajı sular hem evde hem de işyerinde tercih edilmektedir. Bireyler ambalajlı suların sağlıklı ve hijyenik olduğunu düşünmektedirler. Eğitim ve medeni durumun yüksek kaliteye odaklanma ve alışkanlıkları etkilediği görülmektedir. Evliler yüksek kaliteye önem vermiştir. Eğitim seviyesi arttıkça yüksek kaliteye verilen önem de artmaktadır. Fiyat, cinsiyet ve yaş bu açıdan önemli olan diğer faktörlerdir.

Teksoy vd. (2017), Bursa şehri su potansiyelini ortaya koydukları çalışmada, şehrin su zengini olduğu ifade edilmektedir. Bursa gelecek 20 yılın su ihtiyacını karşılayacak potansiyele sahiptir. Şehrin göç alması nedeniyle nüfusu artış halinde olduğundan, planlanmış su kaynakları hizmete geçirilmelidir. Mevcut su ihtiyacı Nilüfer Çayı, Doğancık Barajı, yer altı kuyu suyu ve doğal kaynaklardan sağlanmaktadır. Gelecekteki su ihtiyacı, Nilüfer, Doğancık ve Gölbaşı barajlarından elde edilecektir (Aksoy vd., 2017).

Su talebinin tahmin edilmesi, su alt yapısına yapılan önemli yatırımlar nedeniyle önemli bir konudur. Aslan vd. (2018), Diyarbakır şehrinin içme suyu ihtiyacını genetik ifadeli programlama ile modellenmesini yapmaktadırlar. GEP su mühendisliğinde kullanılan bir tekniktir. GEP'in temel amacı matematiksel bir fonksiyon türetmektir ve bu fonksiyonu GEP'in genel bilgi dizinine adapte edebilmektir. Yapay Zekâ (AI) Tekniği olan GEP, içme suyu talep ve tahmin yönetiminde geliştirilebilir ve kullanılabilir bir metot olarak değerlendirilmektedir. 
Su tüketiminin şehirler içinde ve şehirler arasındaki durumu konusunda yabancı yayın sayısı oldukça fazladır. Aşağıda bunlardan bir kaçı ele alınmaktadır.

Tortajada'ya göre (2006), Meksiko şehri metropoliten alanında sağlanan şehirsel suyun miktar ve nitelik bakımından çeşitli problemleri vardır. Hükümet politikaları diğer şehirlerde yoksulluğun azaltılması, yaşam standartları ve kalitesinin yükseltilmesi yönünde olmuştur. Mevcut eğilim ve yönetim pratikleri değişmedikçe yakın gelecekte de su sağlama problemi devam edecektir. Öyle ki uzak alanlardan ve pahalı kaynaklardan su temini için gerekli yatırım miktarı artacaktır. Bu durum metropoliten alana ekonomik, sosyal ve çevresel olarak olumsuz etkisi olacaktır. Yeraltı suyunun aşırı çekimi çökmeye neden olacağı gibi çekilen suyun kalitesi de düşecektir. Ayrıca işletme ve bakım masrafları da artacaktır.

Praskievicz ve Chang (2007), Seul'de su tüketimi ile meteorolojik koşullar arasındaki ilişkiyi çalışmışlardır. Çalışmanın sonucuna göre, ortalama, minimum ve maksimim sıcaklık ve gündüz uzunluğu su tüketimini olumlu yönde etkilemektedir. Yağış, rüzgâr hızı, nispi nem ve bulutluluk su tüketimini negatif yönde etkilemektedir.

Yoo'nun (2007) tespitlerine göre, yeni sanayileşen bir şehirde (Taejeon-Kore),ekonomik bölgesel gelişimin yaşanması su kullanımında doğrudan artışa neden olmuştur. Bu durum adı geçen şehir için belli bir döneme has bir özellik olabilir. Çünkü ekonomik gelişmeye bağlı olarak geleneksel sanayilerden hafif sanayi ve hizmetlere geçiş söz konusu olur. Bu da su tüketimini azaltır. Yine ekonomik gelişmeye bağlı olarak su tüketiminin azalmasını teşvik eden çevresel düzenlemeler yapıl11r.

Lins vd. (2010), Brezilya'da Campino Grande şehrinde su tüketimini etkileyen faktörleri ele aldıkları çalışmanın sunucuna göre, su tüketimi aile geliri ve su tarifesine bağlı olarak değişmektedir.

Fan vd. (2017), Çin'de 286 şehirde su tüketimini ele aldıkları çalışmanın sonuçlara göre, 130 şehirde, su tüketiminde 2000-2015 yılları arasında önemli değişiklikler yaşanmıştır. 69 şehirde azalma meydana gelmişken, 61 şehirde artış görülmüştür. 112 şehirde kişi başına günlük su tüketimi 70 lt'nın altındaydı. Çin'de kişi başına tüketilen günlük su tüketimini etkileyen faktörler farklıydı. Bu farklılık tüketim gruplarına göre de değişiyordu. Meteorolojik şartlar, sosyo-ekonomik durum, su tedariki ve koruma faktörleri Çin'de kişi başına su tüketimini etkileyen faktörlerdi. Yüksek ölçüde su tüketen şehirlerde yağış, su koruma yatırımları, duş alma ve banyo ihtiyaçlarının karşılanması ve gelir seviyesi tüketimi etkileyen faktörlerdi. Orta ve düşük ölçüde su tüketiminin olduğu şehirlerde, su üretim kapasitesi, sosyo-ekonomik durum, gelir, eğitim ve Engel katsayısı su tüketimini belirlemekteydi. Su tüketimindeki önemli farklılıklar, Çin genelinde, su tüketimine ilişkin farklı politikaların uygulanması gerektiğini göstermektedir.

Baldino ve Sauri (2018), İtalya'nın büyük şehirlerinde su tüketiminin yakın zamanlı azalışını çalıştı. Yaşlı nüfusun fazlalığı ve coğrafi kökeni farklı göçmen nüfusun varlığı su tüketiminin azalmasına neden olmaktadır. Bunlar su tüketimini teşvik edecek araçların az bulunduğu konutlarda yaşamaktadırlar. Başka bir sonuca göre, gelir seviyesi arttıkça su tüketimi azalmaktadır. 
UNESCO (2019) raporu da küresel su sorunu konusunda önemli gerçekleri ortaya koymaktadır. Rapora göre 2015 yılı verilerine göre küresel ölçekte 2.1 milyar insan, evde güvenli, kolay ulaşılabilir suya erişememektedir (UNESCO, 2019). Raporda ayrıca küresel ölçekte suya erişimin çeşitli boyutları ele alınmıştır.

\section{Araştırma Alanı, Materyal ve Yöntem}

Türkiye Cumhuriyeti Çevre ve Şehircilik Bakanlığı, Türkiye Çevre Sorunları ve Öncelikleri Değerlendirme Raporu'na (2019) göre Balıkesir, su kirliliği 1. öncelikli sorun olan iller arasındadır. Su kirliliği, su tüketimi ile doğrudan ilişkili bir konu olduğundan bu çalışmada Balıkesir şehrinde su tüketiminin coğrafi dağılışı ve çeşitli değişkenlerle ilişkisi incelenmiştir.

Çalışma, Balıkesir Büyükşehri Altıeylül ve Karesi idari birimlerinin şehirsel mahallelerini kapsamaktadır. Balıkesir Büyükşehri, Türkiye'nin 26 su havzasından biri olan Susurluk havzasında yer almaktadır. Havza içerisinde 8 tane alt havza ve nehir, göl, kıyı suyu, geçiş suyu gibi 156 yer üstü su kütlesi bulunmaktadır (Şekil 1) (Susurluk Nehir Havzası Yönetim Planı 2018: 2-4). Şehir su ihtiyacını Kille Çayı üzerinde kurulmuş İkizcetepeler barajından karşılamaktadır. Kaynak kısmında Kocadere olarak adlandırılan su, barajdan sonra Kille Çayı adını alır. Alanda en yağışılı mevsim kıştır. $\mathrm{Bu}$ mevsimi ilkbahar ve sonbahar mevsimleri izlemektedir, yaz kurak mevsimdir (Kızılçaoğlu, 2002). Baraj suyunun büyük bir kısmı (\% 84) içme suyu için kullanılmaktadır. Baraj suyu cazibe boruları ile su arıtma tesislerine gönderilmektedir (Foto 1). Arıtılan su borularla şehrin farklı yerlerinde bulunan depolara (Sütlüce, Toygar, Dinkçiler ve 2. Sakarya depoları) aktarılmaktadır. Depolardaki su şehir şebekesiyle bağlantılıdır. Çalışma alanında kuyu suyu da yaygın olarak kullanılmaktadır.

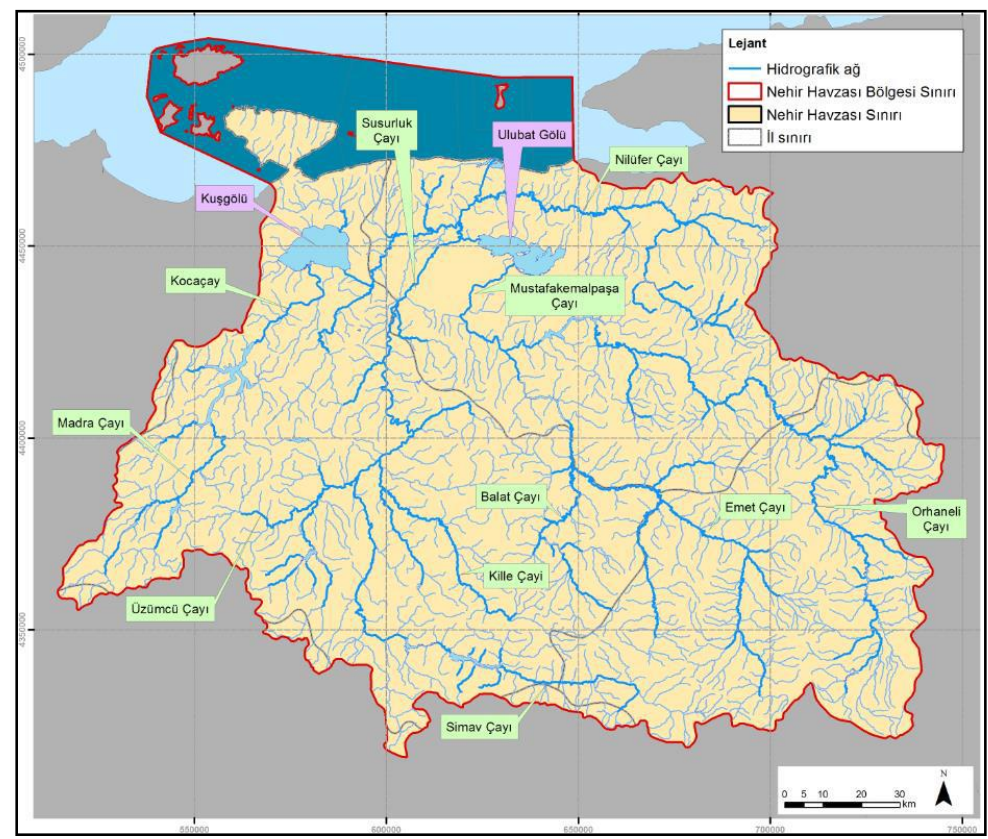

Şekil 1. Susurluk Çayı Havzası akarsu şebekesi

Kaynak: Susurluk Nehir Havzası Yönetim Planı, 2018: 4. 


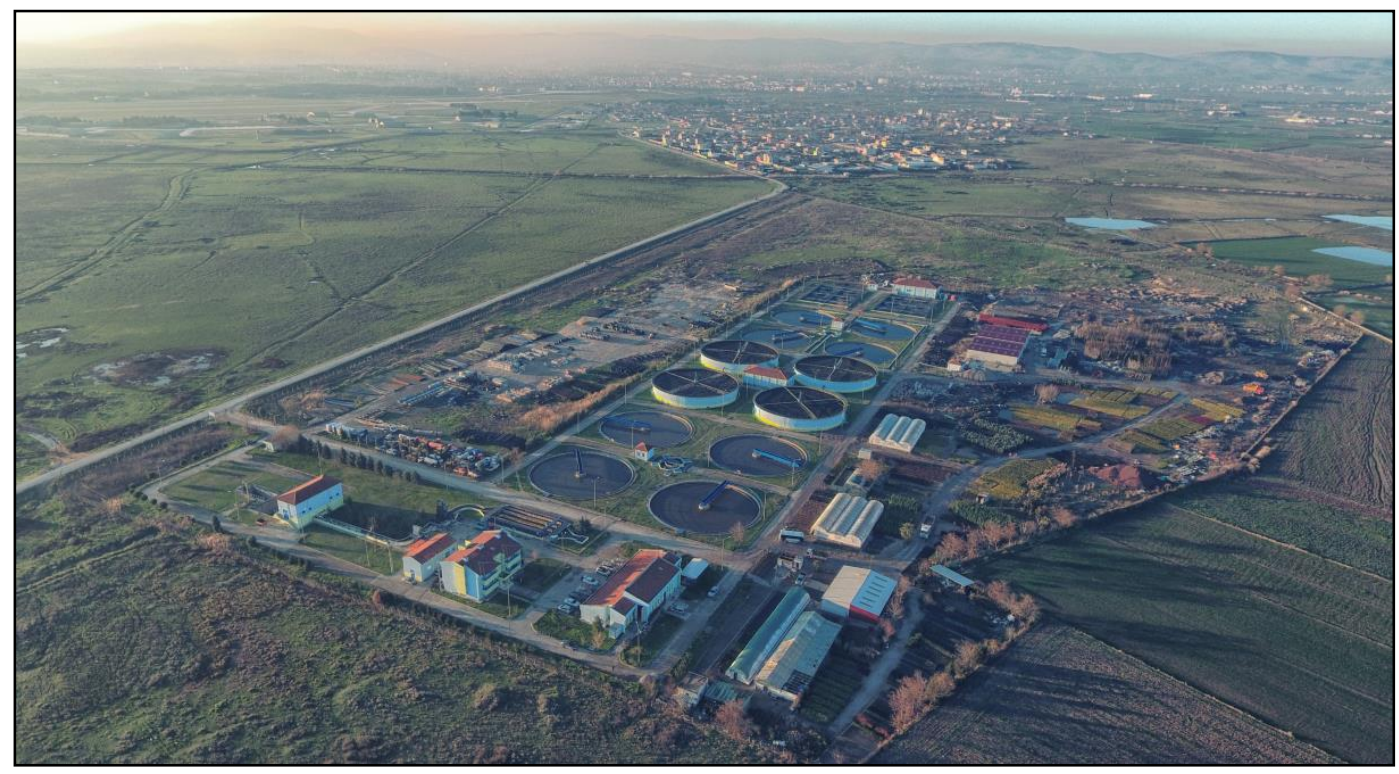

Foto 1: Balıkesir Büyükşehir Belediyesi su arıtma tesisleri

Kaynak: Balıkesir Su ve Kanalizasyon İdaresi

TÜIK 2016 yılı verilerine göre Balıkesir ilinde yıllık dağıtılan su miktarı $56.607 .073 \mathrm{~m}^{3}$ ’tür. $\mathrm{Su}$ bedeli olarak sabit ücret kullanılmakta ve TÜFE verilerine göre su tahsilâtında bedel değişmektedir. Su tüketimi aboneliklere göre farklılaşmaktadır. Dağıtılan toplam su miktarında ise meskenler, ticarethaneler ve resmi kuruluşlar ilk üç sırayı almaktadır (Çizelge 1).

Çizelge 1. Türkiye ve Balıkesir ilinde 2016 yılı dağıtılan su miktarının çeşitli kullanışlara göre durumu

\begin{tabular}{rrr}
\multicolumn{1}{c}{ göre durumu } & TÜRKIYE & BALIKESİR \\
\hline $\begin{array}{r}\text { 2016 y1lı Dağıtılan Su } \\
\text { Miktarı }\left(\mathrm{m}^{3} / \mathrm{Y}_{1}\right)\end{array}$ & 2.720 .330 .390 & 47.524 .863 \\
\hline Meskenler & 304.729 .782 & 3.725 .859 \\
\hline Ticarethaneler & 180.891 .564 & 2.353 .444 \\
\hline Resmi Kuruluşlar & 147.939 .313 & 323.179 \\
\hline Park, Bahçe ve Wc & 91.457 .311 & 13.682 \\
\hline Diğer & 85.474 .710 & 840.629 \\
\hline İnşaatlar & 70.830 .951 & 224.655 \\
\hline Din ve Hayır Kurumları & 66.237 .682 & 150.342 \\
\hline Sanayi İşletmeleri & 43.558 .656 & 922.899 \\
\hline Okullar & 21.424 .810 & 527.521 \\
\hline Sağlık Kurumları & 3.732 .875 .169 & 56.607 .073 \\
\hline Toplam & &
\end{tabular}

Kaynak: http://www.tuik.gov.tr/PreTablo.do?alt_id=1019 adresinden 5.7.2019 tarihinde erişilmiştir.

TÜIK 2016 y1lı verilerine göre Türkiye'de kişi başına çekilen günlük su miktarı 217 litre, Balıkesir için ise bu rakam 238 litredir. Elbette suyun tüketim miktarı, iller, ilçeler, mahalleler, haneler ve bireyler arasında eşit bir dağılım göstermez. Bu kapsamdaki en önemli farklardan biri, su tüketiminin şehirsel alanlarda belirgin bir biçimde artmasıdır. Buna göre verileri incelenen 4 yıl için de Balıkesir'de su tüketiminin şehirsel ve kırsal alanlara göre durumu Şekil 2'de verilmiştir. 


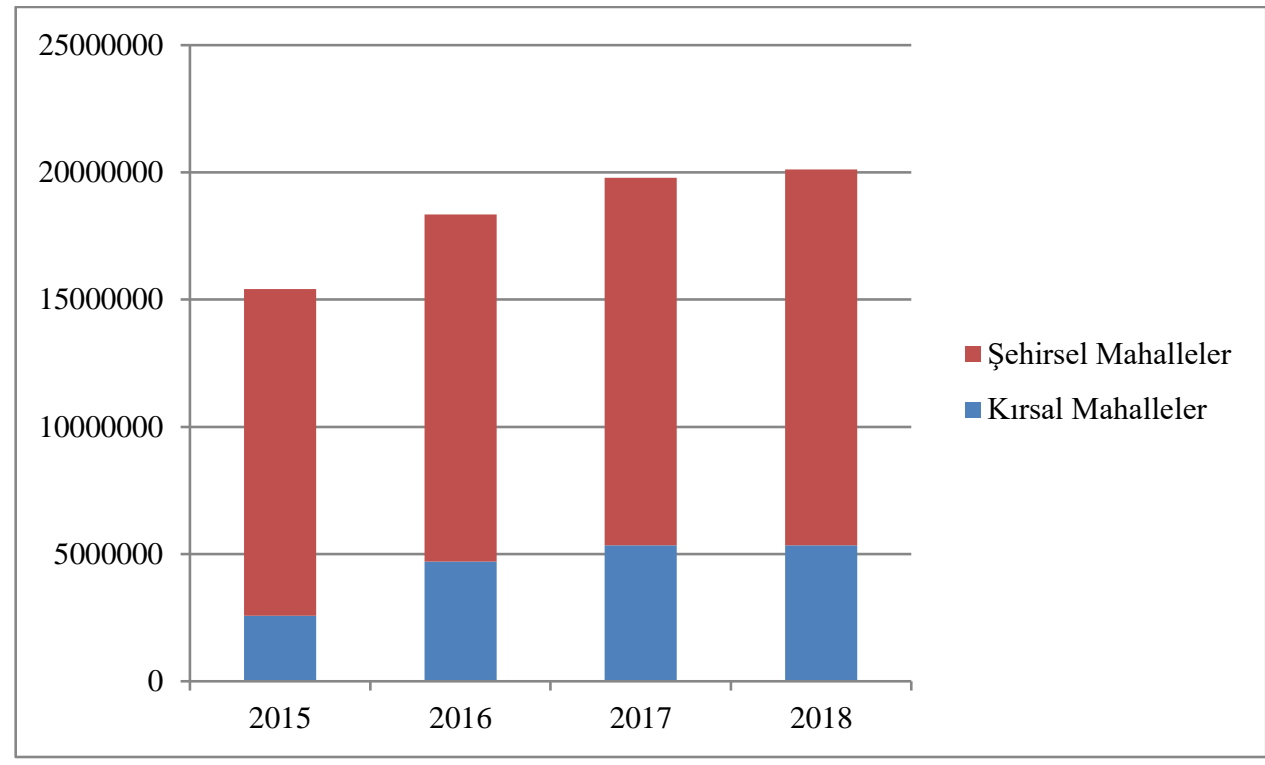

Şekil 2. Balıkesir şehrinde (Karesi ve Altıeylül) su tüketiminin kırsal ve şehirsel mahallelere göre durumu

Kaynak: Balıkesir Su ve Kanalizasyon İdaresi Genel Müdürlüğü'nden (BASKİ) temin edilen verilerle oluşturulmuştur.

Şehirsel mahallelerde artış gösteren su tüketiminin, şehrin mahalleleri arasındaki dağılımı da çeşitli etkenlerle değişiklik gösterir. Bu çalışmada Balıkesir'in şehirsel mahallelerinde, mahallelerin nüfus miktarı, iş yeri sayısı, hane sayısı, gelir düzeyi, eğitim düzeyi ve kuyu suyu aboneliği değişkenlerinin su tüketimi ile ilişkisi korelasyon analizi ile incelenmiştir. Her bir parametre ile su tüketimi arasındaki ilişki basit korelasyon yöntemi ile incelenmiştir. Ancak iki değişken arasındaki ilişki, bu değişkenler dışındaki başka değişkenlerden de kaynaklanabilir (Büyüköztürk, 2019: 34). $\mathrm{Bu}$ nedenle su tüketiminin, değişkenlerden bir ya da birkaçını sabitleyerek diğer değişkendeğişkenlerle olan ilişkisi, kısmi korelasyon yöntemi ile incelenmiştir. Korelasyon analizinde SPPS 16.0 programı kullanılmıştır. Analizlerde kullanılan bağımlı değişken su tüketimi, bağımsız değişkenler ise nüfus miktarı, iş yeri sayısı, hane sayısı, gelir düzeyi, eğitim düzeyi ve kuyu suyu aboneliğidir.

Çalışma kapsamında Balıkesir'in şehirsel mahallelerinde 2015, 2016, 2017 ve 2018 yıllarına ait su tüketim verileri Balıkesir Su ve Kanalizasyon İdaresi Genel Müdürlüğü'nden (BASKİ) temin edilmiştir. Su tüketim verileri bütün abonelikleri kapsamaktadır. İstatistiksel ölçümlerde Balıkesir'in 40 şehirsel mahallesinde son 4 yıllık su tüketiminin ortalaması kullanılmıştır.

Nüfus, iş yeri, gıda yardımı ve kuyu suyu aboneliği için ise 2018 yılı verileri kullanılmıştır. Mahallelere göre 2018 yılı nüfus verileri Türkiye İstatistik Kurumu (TÜIK) resmi web sayfasından, iş yeri verileri ve gıda yardımı verileri Altıeylül ve Karesi belediyelerinden, kuyu suyu aboneliği verileri BASKI'den temin edilmiştir.

Mahallelerin gelir düzeyi ve eğitim düzeyi verileri ise temin edilemediğinden/mevcut olmadığından gelir düzeyi için 2018 yılında mahallelere verilen gıda yardımının mahallenin hane sayısına oranı dikkate alınarak hesaplanmıştır. Mahallerin eğitim düzeyi verileri için de, 
Aliğaoğlu'nun (2007: 70-71) mahallelerdeki yüksekokul mezunlarının mahalle toplam nüfuslarına oranları verisi kullanılmıştır. Hem gelir hem de eğitim düzeyi için yapılan bu istatistiki uyarlama yalnızca bu çalışma için ilişkilendirme yapmak amacıyla üretilmiştir.

Dağılış haritaları ise Balıkesir Büyükşehir Belediyesi planlama biriminden alınan mahalle haritasının ArcGis 10.0 programında düzenlenmesi ve verilerin işlenmesi ile oluşturulmuştur.

\section{Bulgular}

Şehirler büyük ölçüde su tüketmekte ve büyüdükçe su tüketimleri artmaktadır. Su tüketimi, şehirler arasında ve içinde farklılıklar gösterir. Genel olarak gelişmişlik su tüketimini olumlu yönde etkiler. Şehir içi arazi kullanışı da su tüketimini etkilemektedir. İklim, gelir seviyesi, hane halkı sayısı (nüfus miktarı), tüketici davranışları, suyun kalitesi, fiyatı ve alternatif su kaynaklarının varlığı (damacana ve kuyu suyu), inşaat faaliyetleri, kanalizasyon şebekesinin durumu (çift atık su sistemi), kültürel yapı ve su kullanma alışkanlıkları su tüketiminin şehir içi coğrafî dağıllışını etkileyen diğer nedenlerdir (Uğur ve Aliağaoğlu, 2018).

Öncelikle incelenen 40 şehirsel mahallede, 2015 yılında tüketilen yıllık su miktarı ile 2018 yılında tüketilen yıllık su miktarı arasındaki fark 2.007.948 $\mathrm{m}^{3}$ ' tür. Buna göre incelenen mahallelerde yıllık su tüketim miktarının 4 yıllık artış ortalaması $669.316 \mathrm{~m}^{3}$ ’tür.

Balıkesir şehirsel mahallelerinde 4 yıllık su tüketimi ortalamasının mahallelere göre dağılımı incelendiğinde maksimum su tüketiminde $1.710 .422 \mathrm{~m}^{3}$ ile Bahçelievler Mahallesi ilk sırayı alırken, $35.203 \mathrm{~m}^{3}$ ile 2. Oruçgazi Mahallesi son sıradadır. Ancak daha önce belirtildiği gibi su tüketimi mahalleler, haneler ve bireyler arasında da eşit bir dağılım göstermez. Nitekim yıllık su tüketim miktarı sıralamasında en fazla su tüketiminde Bahçelievler Mahallesi ilk sırayı alırken, kişi başına düşen yıllık su miktarı sıralamasında $168 \mathrm{~m}^{3}$ ile Eskikuyumcular Mahallesi ilk sıradadır (Şekil 3). Fakat bu veri de, incelenen mahalleler arasında Eskikuyumcular Mahallesi'nde ikamet eden bireylerin maksimum su tükettiği bilgisini vermez. Çünkü bir mahalledeki su tüketimi, orada yaşayan bireyler arasında eşit dağılmadığı gibi, yalnızca orada yaşayan bireylere de ait değildir. Örneğin incelenen mahallelerde en fazla su tüketimi Bahçelievler Mahallesi'ne ait iken, kişi başına kullanılan su miktarı bakımından Eskikuyumcular Mahallesi'nin ilk sırayı alması, Eskikuyumcular Mahallesi’nin Merkezi İş Alanı'nda (MİA) yer alması ile ilişkilidir.

Şehir merkezinde, bilgi veren, yöneten ve kar getiren faaliyetlerin toplandığı alanı ifade eden merkezi iş alanı, nüfusun yoğunluğunun gündüzleri fazla, geceleri ise az olduğu alandır. $\mathrm{Bu}$ bakımdan Eskikuyumcular Mahallesi'nde gündüz iş alanlarının ve iş alanları aracılığıyla şehrin diğer mahallelerinden gelen nüfusun tükettiği su miktarı, kişi başına düşen su tüketimini, istatistiki olarak arttırmaktadır. Tüketilen su miktarı ve kişi başına düşen kullanılan su bakımından ilk sırayı almaları nedeniyle Bahçelievler ve Eskikuyumcular mahalleleri üzerinden örneklenen bu ilişki, Şekil 3'den de açık bir şekilde izlenebilir. Bu bakımdan yıllık su tüketim miktarının en fazla olduğu ilk 5 mahalle (Bahçelievler, Paşaalanı, Toygar, Atatürk, Plevne), nüfus miktarının da en fazla olduğu ilk 5 mahalledir (Bahçelievler, Paşaalanı, Atatürk, Toygar, Plevne). Kişi başına yıllık su tüketim miktarının $\left(\mathrm{m}^{3}\right)$ en fazla olduğu ilk 5 mahallenin (Eskikuyumcular, Akıncılar, Dumlupınar, Yıldırım, 
Hisariçi) ise hiçbiri nüfus miktarı ya da yıllık su tüketim miktarının en fazla olduğu ilk 5 mahalle değildir.

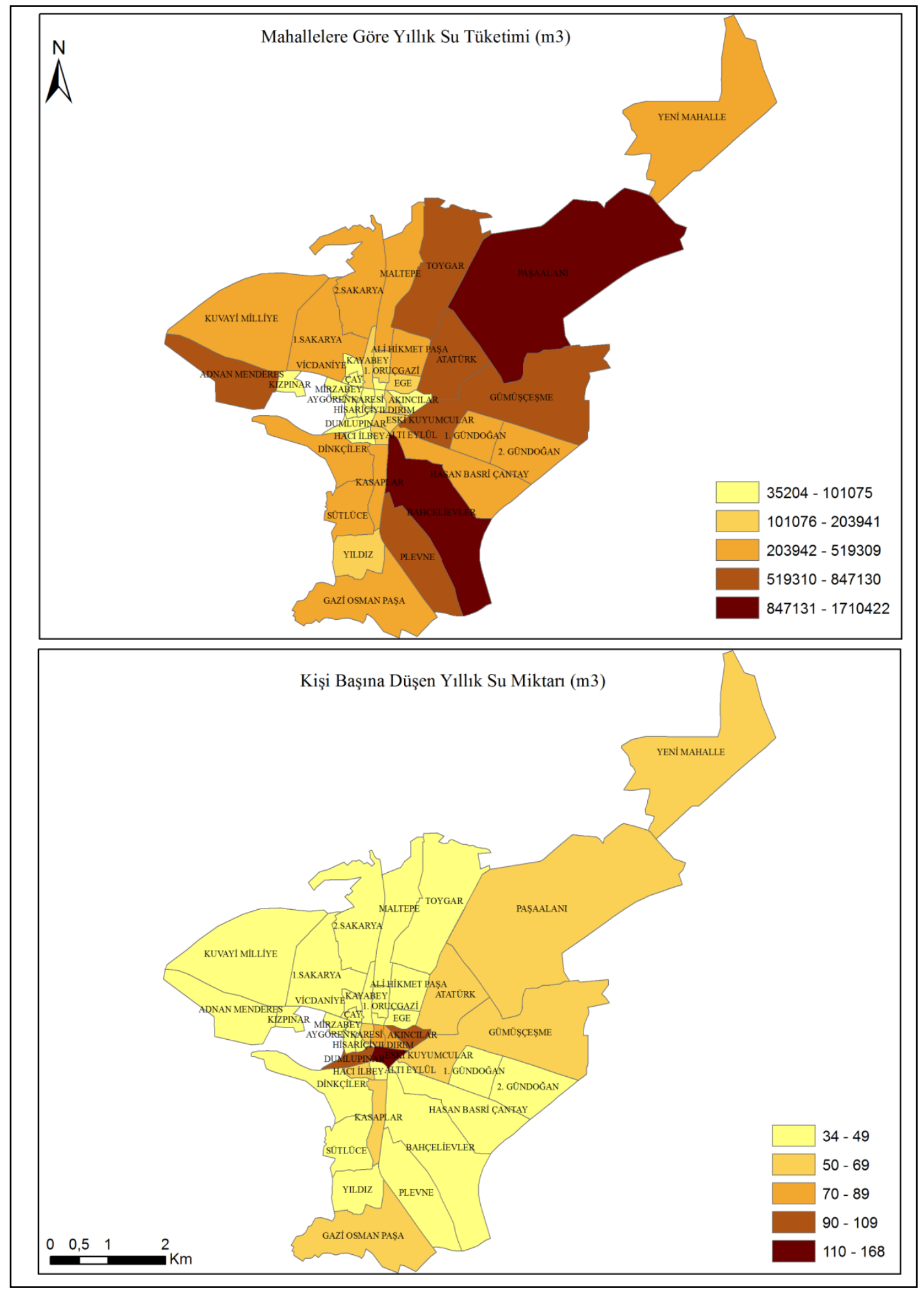

Şekil 3. Balıkesir şehrinde mahallelere göre su tüketimi ve kişi başına su tüketim miktarı (2015-2018 yılları ortalamas1) 


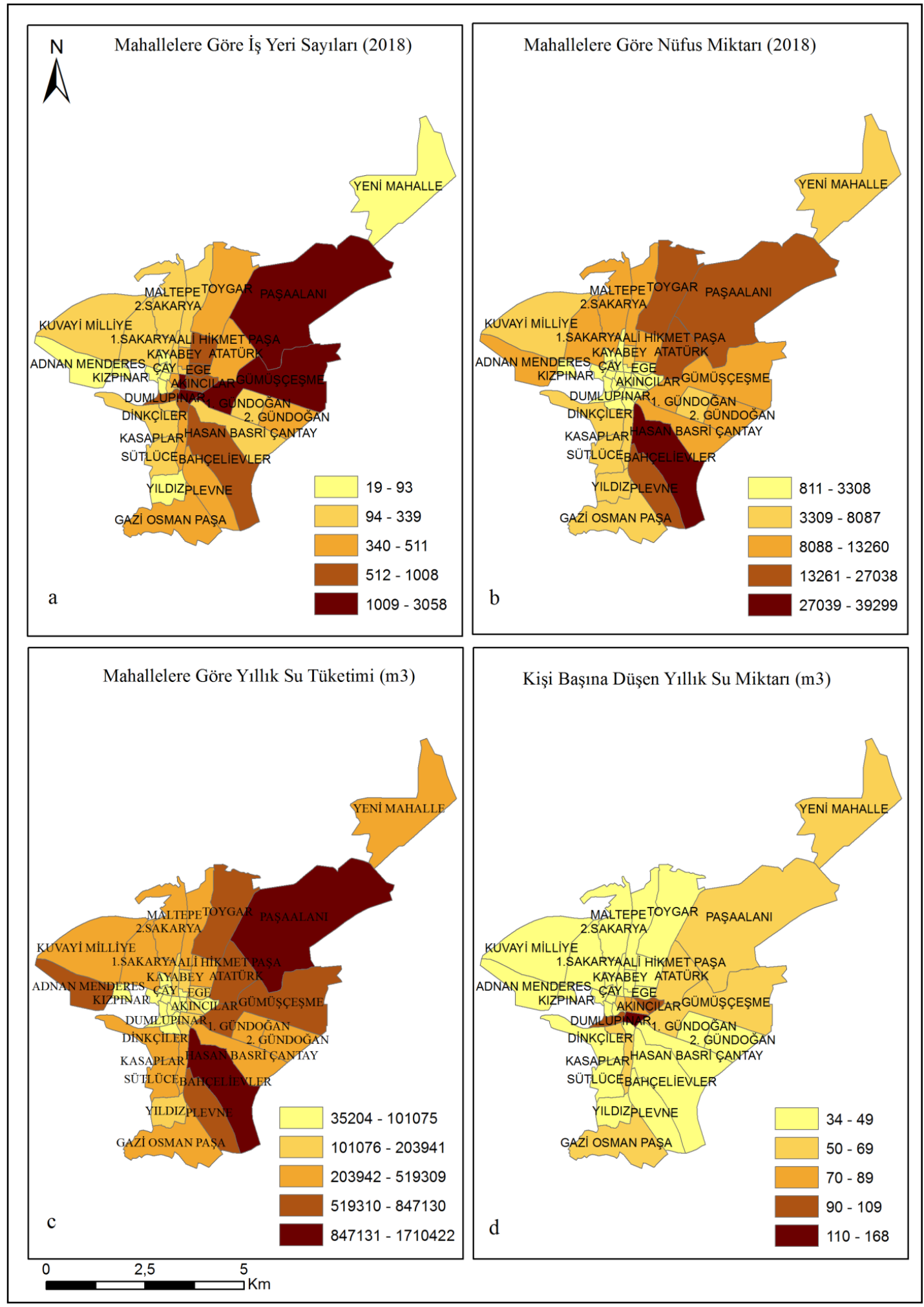

Şekil 4. Balıkesir şehrinde iș yeri, nüfus, su tüketimi ve kişi başına düșen su tüketim miktarının mahallelere göre dağılış1*

* Su tüketimi ve kişi başına düşen su tüketimi verileri 2015, 2016, 2017 ve 2018 yıllarının ortalamasıdır. 
Aynı zamanda kişi başına yıllık su tüketim miktarının $\left(\mathrm{m}^{3}\right)$ en fazla olduğu ilk 5 mahalle (Eskikuyumcular, Akıncılar, Dumlupınar, Yıldırım, Hisariçi) de merkezi iş alanının bulunduğu alana tekabül etmektedir (Şekil 4). Bu bulgu su tüketimi ile iş yeri arasındaki ilişkiye işaret etmektedir. Bu ilişkinin düzeyi korelasyon yöntemi ile incelenmiştir.

Büyüköztürk'e göre (2019: 32), incelenen iki değişken arasındaki korelasyon katsayısının 0.00 olması iki değişken arasında ilişki olmadığını, 1.00 olması pozitif ilişkiyi, -1.00 olması ise negatif ilişki olduğunu gösterir. 0.00 ile 0.30 arasındaki korelasyon katsayısı düşük düzeyde, 0.30 ile 0.70 arasındaki korelasyon katsayısı orta düzeyde, 0.70 ile 1.00 arasındaki korelasyon katsayısı da yüksek düzeyde bir ilişki olduğunu gösterir (Büyüköztürk, 2019: 32). Buna göre iki değişken arasındaki korelasyon katsayısı 1.00'e yaklaştıkça ilişki düzeyi artarken 0 'a yaklaştıkça ilişki düzeyi azalır.

Korelasyon analizine göre incelenen mahallelerin yıllık su tüketim miktarı ile nüfus miktarı arasında yüksek düzeyde anlamlı, pozitif bir ilişki vardır $(\mathrm{r}=0.980)$. Mahallenin nüfus miktarı arttıkça toplam su tüketimi de artmaktadır. İş yeri sayısı ve yıllık su tüketimi miktarı arasında ise orta düzeyde anlamlı bir ilişki vardır $(\mathrm{r}=0.365)$. İş yeri sayısı arttıkça su tüketimi de artmaktadır fakat aralarındaki ilişki düşüğe yakın, orta düzeydedir.

Çizelge 2. Korelasyon Değerleri

\begin{tabular}{cc}
\hline Değişkenler & Korelasyon Değerleri \\
\hline Su tüketim miktarı $\left(\mathrm{m}^{3}\right)$-Nüfus & 0.980 \\
\hline Su tüketim miktarı $\left(\mathrm{m}^{3}\right)$-İş yeri sayısı & 0.365 \\
\hline Kişi başına su tüketim miktarı $\left(\mathrm{m}^{3}\right)$-Nüfus & -0.242 \\
\hline Kişi başına su tüketim miktarı $\left(\mathrm{m}^{3}\right)$-İş̧ yeri sayısı & 0.558 \\
\hline
\end{tabular}

Korelasyon katsayısına göre, mahallelerin iş yeri sayısı ile kişi başına su tüketim miktarı $\left(\mathrm{m}^{3}\right)$ arasında ise orta düzeyde anlamlı, pozitif bir ilişki vardır $(r=0.558)$. Buna göre mahalle düzeyinde iş yeri sayısı arttıkça kişi başına düşen/1 kişinin harcadığı su miktarı artmaktadır. Ancak gerçekte bunun böyle olması beklenmez. Çünkü iş yerlerinin arttı̆̆ yerler ikamet eden nüfusun azaldığ yerlerdir. İş yeri sayısı arttıkça kişi başına tüketilen su miktarının artması, bir yandan bu bölgelerde iş yerleri aracılığıyla artan su tüketimi, bir yandan da iş sahalarının, nüfus miktarının azaldığı yerler olması ile ilgilidir.

Kişi başına su tüketim miktarı $\left(\mathrm{m}^{3}\right)$ ile nüfus arasında ise düşük düzeyde negatif bir ilişki vardır $(r=-0.242)$. Buna göre nüfus arttıkça kişi başına düşen su tüketimi azalmaktadır. Gerçekte nüfus arttıkça kişi başına kullanılan suyun azalması beklenir ancak kişi başına su tüketim miktarı ile nüfus arasındaki ilişki düzeyinin düşük olması, su tüketimine ilişkin diğer parametrelerin etkisini göstermektedir. Aksi halde aralarında yüksek düzeyde negatif bir ilişki olması beklenirdi. Nitekim kişi başına düşen su miktarının en fazla olduğu mahallelerin hiçbiri (Eskikuyumcular, Akıncılar, Dumlupınar, Yıldırım, Hisariçi), nüfus miktarının en fazla olduğu mahalleler (Bahçelievler, Paşaalanı, Atatürk, Toygar, Plevne) değildir. Bu nedenle her bir parametre ile su tüketimi arasındaki ilişkiyi, diğer parametrelerin etkisini kontrol ederek analiz eden kısmi korelasyon analizi yapılmıştır. 
Kısmi korelasyon analizinde iş yeri verisi sabit tutulduğunda nüfus ve y1llık su tüketim miktarı arasında yine yüksek düzeyde anlamlı pozitif ilişki ( $\mathrm{r}=0.980)$, nüfus verisi sabit tutulduğunda ise iş yeri ve yıllık su tüketim miktarı arasında bu kez yüksek düzeyde anlamlı ilişki vardır ( $\mathrm{r}=0.698)$. Nüfus verisi sabit tutulduğunda kişi başına düşen $\mathrm{m}^{3}$ ile iş yeri arasında orta düzeyde anlamlı pozitif ( $\mathrm{r}=0.653$ ), iş yeri verisi sabit tutulduğunda nüfus ile kişi başına düşen $\mathrm{m}^{3}$ arasında orta düzeyde anlamlı negatif bir ilişki vardır $(r=-0.464)$.

Çizelge 3. Kısmi Korelasyon Sonuçları

\begin{tabular}{|c|c|}
\hline Değişkenler & Korelasyon Değerleri \\
\hline $\begin{array}{l}\text { İs yeri verisi sabit tutulduğunda: Su tüketim } \\
\text { miktarı }\left(\mathrm{m}^{3}\right) \text {-Nüfus ilişkisi }\end{array}$ & 0.980 \\
\hline $\begin{array}{l}\text { Nüfus verisi sabit tutulduğunda: Su tüketim } \\
\text { miktarı }\left(\mathrm{m}^{3}\right) \text {-İş yeri sayısı ilişkisi }\end{array}$ & 0.698 \\
\hline $\begin{array}{l}\text { İş yeri verisi sabit tutulduğunda: Kişi başına } \\
\text { düşen } \mathrm{su}\left(\mathrm{m}^{3}\right) \text {-Nüfus ilişkisi }\end{array}$ & -0.464 \\
\hline $\begin{array}{l}\text { Nüfus verisi sabit tutulduğunda: Kişi başına } \\
\text { düşen su miktarı }\left(\mathrm{m}^{3}\right) \text {-İş yeri sayıs ilişkisi }\end{array}$ & 0.653 \\
\hline
\end{tabular}

Su tüketimi ve kişi başına düşen yıllık su miktarı $\left(\mathrm{m}^{3}\right)$ ile iş yeri ve nüfus verileri korelasyon analizi sonuçlarına göre mahallelere göre su tüketimini açıklayan en önemli değişken nüfus miktarıdır $(\mathrm{r}=0.980)$. Ancak iş yeri sayısı da su tüketiminin önemli bir açıklayıcısıdır ( $\mathrm{r}=0.698)$. Nüfus miktarı arttıkça su tüketiminin artması beklenen bir sonuçtur. Bu kapsamda su tüketimi ile nüfusun özelliklerinin ilişkisinin incelenmesi gerekir. Hane sayısı, hane büyüklüğü, nüfusun yaş ortalaması, gelir düzeyi, iş durumu, eğitim düzeyi gibi demografik değişkenler su tüketimini etkiler.

İncelenen mahallelerde su tüketim miktarı ile hane sayısı arasında yüksek düzeyde anlamlı pozitif bir ilişki vardır $(r=0.972)$. Bu noktada hane büyüklüğü de önem kazanır ancak mahallelere göre hane büyüklüğü verisine ulaşılamamıştır. Su tüketim miktarı ile eğitim düzeyi arasında ise düşüğe yakın orta düzeyde anlamlı pozitif bir ilişki vardır ( $\mathrm{r}=0.397)$. Ayrıca yaşanan bölgede su bedeli ya da kuyu suyu aboneliği gibi yerel koşullar da su tüketimini etkiler. Nitekim su bedeli her yerde aynı değildir. Ya da örneğin Balıkesir yerelinde kuyu suyu aboneliği olanağı su fatura bedelini düşüren bir parametre olarak su tüketimini teşvik edebilir. Bu bakımdan Balıkesir'de sudan çok atık suyun uzaklaştırılması için ücret ödenmektedir. Korelasyon analizi sonuçlarına göre kuyu suyu aboneliği ile su tüketim miktarı arasında da yüksek düzeyde anlamlı pozitif bir ilişki vardır ( $\mathrm{r}=$ $0.825)$.

Çizelge 4. Korelasyon Değerleri

\begin{tabular}{cc}
\hline Değişkenler & Korelasyon Değerleri \\
\hline Su tüketim miktarı $\left(\mathrm{m}^{3}\right)$-Hane sayısı & 0.972 \\
\hline Su tüketim miktarı $\left(\mathrm{m}^{3}\right)$-Gıda Yardım Oranı & 0.572 \\
\hline Su tüketim miktarı $\left(\mathrm{m}^{3}\right)$-Eğitim Düzeyi & 0.397 \\
\hline Su tüketim miktarı $\left(\mathrm{m}^{3}\right)$-Kuyu suyu aboneliği & 0.825 \\
\hline
\end{tabular}




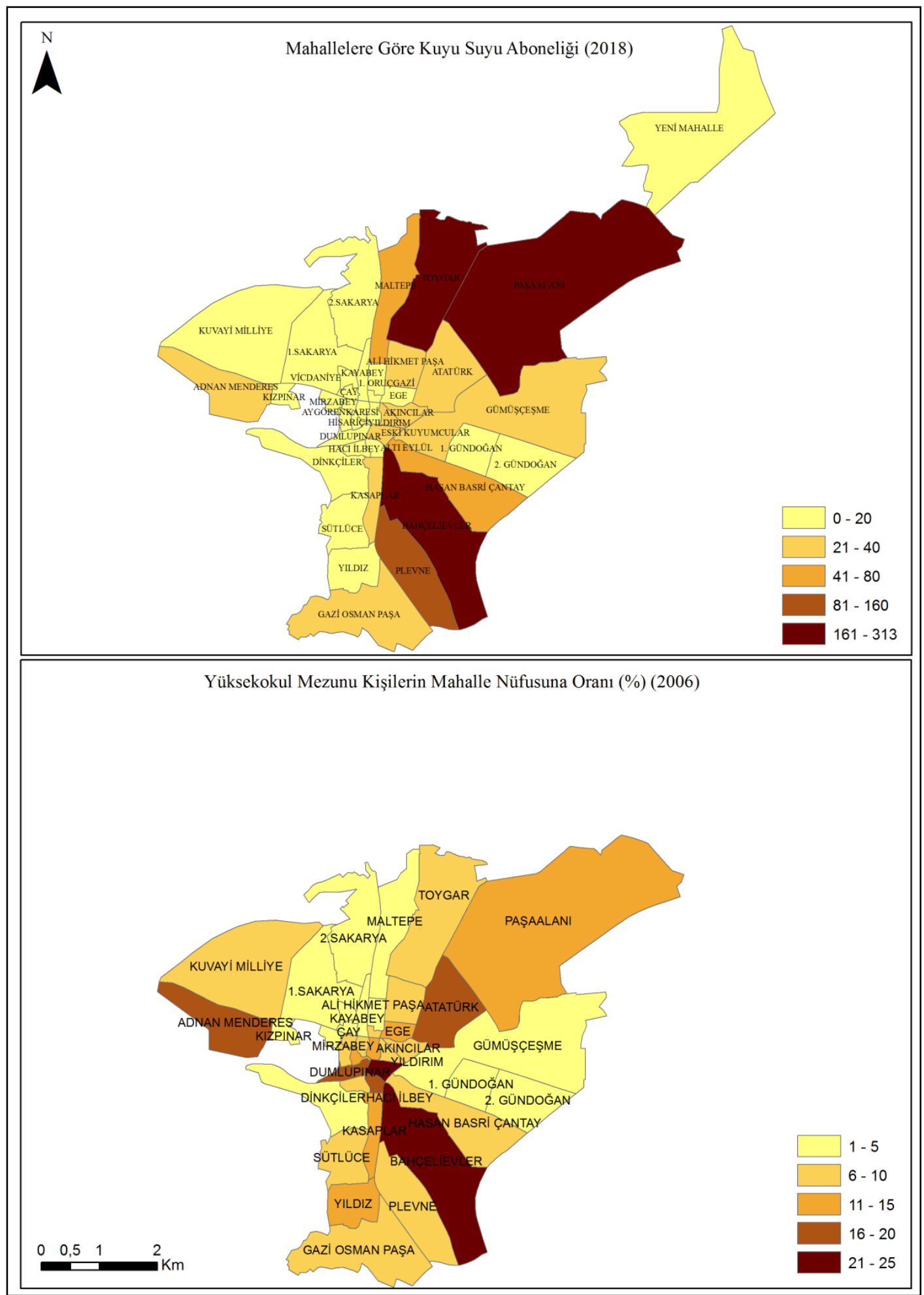

Şekil 5. Balıkesir kentinde eğitim düzeyi ve kuyu suyu aboneliğinin mahallelere göre dağıllşı1

* Yüksekokul mezunu kişi sayısının mahalle nüfusuna oranı (2006) yılı verisi olduğundan, Yenimahalle bu haritada gösterilmemiştir. 
Korelasyon analizi sonuçlarına göre mahallelerin hane sayısı ve kuyu suyu aboneliği su tüketiminin yüksek düzeyde açıklayıcılarıdır. Diğer bir ifadeyle mahalle ölçeğinde hane sayısı ve kuyu suyu aboneliği arttıkça su tüketimi de artmaktadır. Eğitim düzeyi ile su tüketimi arasındaki ilişki ise düşüğe yakın orta düzeyde olmakla beraber eğitim düzeyi arttıkça su tüketiminin de arttığını göstermektedir. Ancak bu sonuç, su tüketimi ile ilgili diğer değişkenlerin ortak etkisi ile ilgili bir sonuçtur. Nitekim örneğin Bahçelievler Mahallesi eğitim düzeyi en yüksek mahallelerden biri olmakla beraber aynı zamanda su tüketimini teşvik eden kuyu suyu aboneliğinin ve nüfusun da en fazla, böylece su tüketiminin de en fazla olduğu mahalledir (Şekil 4 ve 5).

Eğitim düzeyi arttıkça, bireylerin tasarruf ve doğal kaynakların sürdürülebilirliği konusunda bilinçlenmeleri aracılığıyla, su tüketiminin azalması beklenir. Ancak bu, mahalle düzeyinde incelendiğinde, yukarıda örneklendiği gibi nüfus miktarı ya da su bedeli gibi değişkenlerden de bağımsız değildir. Ayrıca gelir düzeyi de bu bağlamda önemli bir değişken olarak düşünülebilir.

İncelenen mahallelerde gelir düzeyi verisi bulunmadığından, mahallelere yapılan gıda yardımından mahallelerin gelir düzeyi çıkarımına gidilmiştir. Buna göre gıda yardım oranı (hane sayısı/gıda yardımı alanların sayısı) en fazla olan mahalleler gelir düzeyi en düşük mahalleler olarak kabul edilmiştir. Korelasyon analizine göre gıda yardım oranı ile su tüketimi arasında da orta düzeyde anlamlı pozitif bir ilişki vardır $(\mathrm{r}=0.572)$. Buna göre gıda yardım oranı arttıkça, diğer bir ifadeyle gelir düzeyi azaldıkça su tüketimi artmaktadır.

Gelir düzeyinin artması su tüketimini farklı şekillerde etkiler. Bu durum bir yandan bilinçli kullanım aracılığıyla su tüketiminin azalması bir yandan da yaşam standartları (ev dışında vakit geçirme, bulaşık makinesi kullanma, bazı temizlik işlerinin (kuru temizleme, halı yıkama, kişisel bakım vb.) ev dışında gerçekleşmesi) bakımından da mahalle ölçeğinde su tüketim miktarını etkiler. Balıkesir şehri örneğinde ise mahalle ölçeğinde gelir düzeyi azaldıkça su tüketiminin arttığ1 görülmektedir.

Ancak ayrıca, mahallelerin nüfus miktarının aynı olmaması bakımından, mahallelerin toplam su tüketimi ile hane sayısı, gelir düzeyi, eğitim düzeyi, kuyu suyu aboneliği parametreleri arasındaki ilişkinin yanı sıra mahallelere göre kişi başına düşen su tüketimi ile bu parametreler arasındaki ilişki incelenmelidir. Bu bakımdan kişi başına düşen yıllık su tüketim miktarı ile gıda yardım oranı arasında da yine orta düzeyde anlamlı pozitif bir ilişki vardır $(r=0.416)$. Buna göre de gıda yardım oranı arttıkça, diğer bir ifadeyle gelir düzeyi azaldıkça kişi başına yıllık su tüketimi artmaktadır.

Mahallelere göre kişi başına düşen yıllık su tüketim miktarı ile hane sayısı arasında ise bu kez düşük düzeyde anlamlı negatif bir ilişki vardır $(\mathrm{r}=-0.245)$. Buna göre mahallelere göre hane sayısı arttıkça kişi başına su tüketim miktarı azalmaktadır. Ancak yine de mahallelere göre hane sayısı, kişi başına su tüketiminin düşük düzeyde açıklayıcısıdır. Bu konuda daha önce belirtildiği gibi hane büyüklüğ̈̈ konusu önem kazanmaktadır.

Mahallelere göre kişi başına yıllık su tüketim miktarı ile eğitim düzeyi arasında ise orta düzeyde anlamlı pozitif bir ilişki vardır $(r=0.445)$. Mahallelere göre kişi başına yıllık su tüketim 
miktarı ile kuyu suyu aboneliği arasında ise çok düşük düzeyde anlamlı, negatif bir ilişki vardır (r= -0.014). Buna göre kuyu suyu aboneliği arttıkça kişi başına su tüketimi azalmaktadır. Ancak bu ilişki düzeyi son derece düşüktür (Çizelge 5).

Çizelge 5. Korelasyon Değerleri

\begin{tabular}{cc}
\hline Değişkenler & Korelasyon Değerleri \\
\hline Kişi başına düşen yıllık su tüketim miktarı-Hane sayısı & -0.245 \\
\hline Kişi başına düşen yıllık su tüketim miktarı -Gıda yardım oranı & 0,416 \\
\hline Kişi başına düşen yıllık su tüketim miktarı -Eğitim Düzeyi & 0,445 \\
\hline Kişi başına düşen yıllık su tüketim miktarı -Kuyu suyu aboneliği & $-0,014$ \\
\hline
\end{tabular}

\section{Sonuç}

Hayat kaynağı olan su az bulunan ve doğal olarak farklı şekillerde var olan bir kaynaktır. Denizler, akarsular, kuyular, arıtma tesisleri, barajlar, su depoları, kanalizasyon, su dağıtım şebekesi ve çeşmeler şehirsel mekânın dokusu içinde şehirsel hidrografyanın başlıca elemanlarıdır. Çeşitli faaliyetlerin yerine getirilmesi su ile mümkündür. Su tüketimi, iklim, nüfus büyüklüğü, gelir seviyesi ve şehirsel işlevlere göre değişmektedir. Konut alanlarında bile su tüketimi farklılaşmaktadır. Bu bağlamda şehirsel su tüketiminin coğrafi dağılışı önemlidir. Bu dağılışı etkileyen nedenler bulunmaktadır. Bu çalışmada Balıkesir şehrinde su tüketiminin dağılışını etkileyen faktörler ele alınmıştır.

Kentler su tüketiminin yoğunlaştığı yerleşim birimleridir. Kuşkusuz bunun öncelikli nedeni nüfusun büyük ölçüde kentlerde toplanmasıdır. Bahçelievler Mahallesi Balıkesir'de su tüketiminin en fazla olduğu mahalledir. Korelasyon analizine göre de, incelenen mahallelerde nüfus miktarı, su tüketiminin önemli bir açıklayıcısıdır ( $\mathrm{r}=0.980$ ). Ancak nüfusun coğrafi dağılışı ile kişi başına düşen su tüketim miktarının coğrafi dağılışı arasındaki farklılıklar, su tüketimine ilişkin diğer parametrelerin önemine işaret etmektedir. Bu bakımdan kişi başına düşen su tüketim miktarının en fazla olduğu mahallelerin, merkezi iş alanının bulunduğu bölgeye tekabül etmesi, su tüketimi ile iş yerleri arasındaki ilişki ile ilgilidir. Bu bakımdan mahallelerin iş yeri sayısı da su tüketiminin orta düzeyde anlamlı bir açıklayıcısıdır. Yanı sıra su tüketimi, haneler ve bireyler arasında da değişiklik gösterir. Bu bakımdan eğitim düzeyi, gelir düzeyi gibi değişkenler su tüketimini doğrudan ve dolaylı olarak etkiler.

Analiz sonuçlarına göre mahallelerin gelir düzeyi azaldıkça su tüketimi artarken, eğitim düzeyi ile su tüketimi arasında orta düzeyde bir ilişki vardır. Gelir ve eğitim düzeyinin, bilinçlenme, yanı sıra evde veya ev dışında vakit geçirme, temizlik ve yemek işlerinin ev dışında gerçekleşmesi gibi değiş̧kenlerle su tüketimini azaltması beklenir. Eğitim düzeyi, gelir düzeyi vb. su tüketimi açısından önemli değişkenlerdir ancak bireyin dünya görüşü, doğaya bakış açısı, duyarlılık düzeyi gibi öznel değerler de son derece önemlidir. Bu kapsamda bilinçli olmak kadar duyarlı olmak konusu da önem kazanır. Ayrıca ölçümlerdeki değişkenlerden her biri, diğer değişkenlerden bağımsız değildir. Bu nedenle eğitim düzeyi, gelir düzeyi gibi değişkenlerin su tüketimi ile ilişkisi kuşkusuz mahalle ölçeğinde diğer değişkenlerden (nüfus miktarı, iş yeri sayısı vb.) de bağımsız değildir. 
Ayrıca yerel koşullar da su tüketimini etkiler. Nitekim su bedeli her ilde aynı değildir. Örneğin Balıkesir yerelinde kuyu suyu aboneliği su bedelini düşüren bir parametredir. Yine su tüketimine dair yerel bir parametre olarak Balıkesir, kamu çeşmelerinin yaygın olduğu bir kenttir. Bu bakımdan mahallelere göre su tüketimi verisinin kamu çeşmeleri ile ilişkisi düşünüldüğünde gelir düzeyinin düştüğü mahallelerde su tüketiminin artmasında, suyun kamu çeşmelerinden temin edilmesi gibi bir etki de söz konusu olabilir. Bu bakımdan bu çalışma mahallelere göre su tüketiminin coğrafi dağılışı ve su tüketimini etkileyen bazı değişkenlerin anlam düzeyini ortaya koymaktadır fakat su tüketiminde bireysel değişkenler ve görünenin arkasındaki gerçeklikler de ayrı bir çalışma olarak ele alınmalıdır. Bu bakımdan hane ve birey ölçeğinde, gündelik yaşamda su tüketiminin belirleyicileri incelenmelidir. 


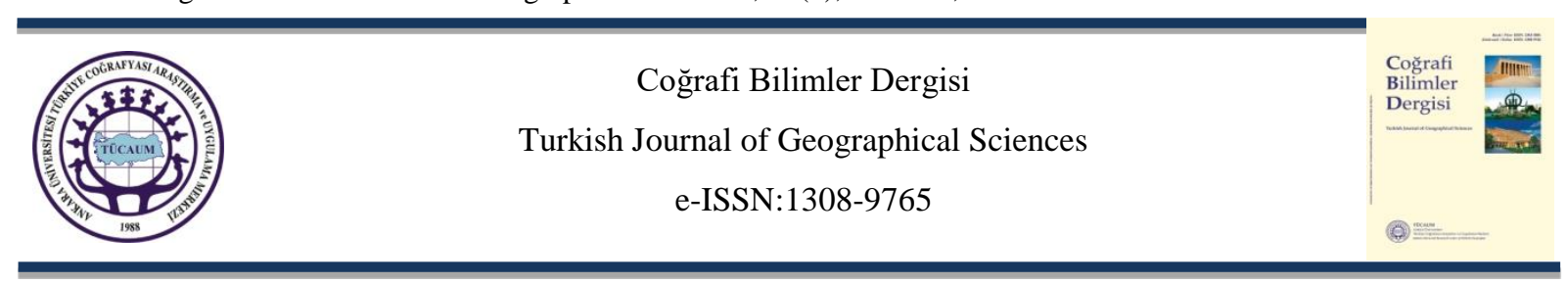

\title{
Water Consumption in Balıkesir City: A Geographical Approach
}

\author{
Alpaslan Aliağaoğlu*a, Güldane Mirioğlu ${ }^{\mathrm{b}}$
}

\section{EXTENDED ABSTRACT}

\section{Introduction}

Water, which is one of the main natural sources on earth, is essential for humans as well as the existence of natural life. Even though water is one of the main natural sources on earth, the water resources in the world are not distributed equally and very little of the available water can be used. Water is essential for humans as well as for the existence of natural life. Water, which is a physiological necessity and habitat, is used for different purposes.

Settlements consume water in different ways such as drinking water and utility wateragricultural irrigation, continuation of natural life, cleaning of the city, industrial production (use and cooling water), tourism activities, fishing and so on. Due to the population growth, climate change, developments in industry and technology and changes in lifestyles, water consumption is increasing

Water infrastructure is like the blood vessel of cities. Everything such as visual beauties, cleaning, physiological needs, removal of pollutants, industrial and energy production all depend on the presence of water. However, the relationship between the city and water is not one-way. As the existence of cities depends on water, urbanization, industrialization and technological developments may cause water pollutions and floods.

Water consumption in cities may vary depending on the population size, income level, climate and activities in the city. Water consumption also differs in urban areas depending on functional characteristics. The water requirement of residential areas is not same as the water requirement of commercial workplaces. In this context, the type of workplaces also affects the water consumption. The rate of water consumption in residential also depend on household population, number of households, income level, traditions and water consumption behaviours etc.

In this study, geographical distribution of water consumption in Balıkesir city will be discussed. Balıkesir is among the provinces in which water pollution is the first priority problems in Turkey (Türkiye Cumhuriyeti Çevre ve Şehircilik Bakanlığı, Türkiye Çevre Sorunları ve Öncelikleri Değerlendirme Raporu, 2019). Knowing the geographical distribution of water consumption and the reasons which affecting will make a significant contribution to the effective use of water resources, urban planning and decision-making process.

\footnotetext{
* Corresponding Author: alpaslan38ster@gmail.com

${ }^{a}$ Balikesir University, Departmant of Geography, Balıkesir, Turkey, http://orcid.org/0000-0002-6198-3878.

${ }^{\mathrm{b} B a l i k e s i r}$ University, Departmant of Geography. Balıkesir, Turkey, http://orcid.org/0000-0003-3191-5935.
} 


\section{Field of the study}

This study focuses on the urban neighbourhoods of Balıkesir Metropolitan Municipality, Altıeylül and Karesi administrative units. The metropolitan city of Balıkesir is located in Susurluk basin, which one of the 26 watershed basins of Turkey. The city's water requirement is supplied by İkizcetepeler dam which is established on the Kille Stream. According to the data provided by the Turkish Statistical Institute (TUIK,2016), the annual amount of water distributed in Balikesir province is (in that particular year was?) $56,607,073 \mathrm{~m}^{3}$. In the total amount of water distributed, the top three (consumers) are dwellings, commercial workplaces and governmental organizations (TÜIK, 2016). According to TUIK (2016), the amount of water consumed daily per capita was 217 litres in Turkey while this number was 238 litres in Balıkesir. Of course, the amount of water consumption does not have an equal distribution among provinces, districts, neighbourhoods, households and individuals. One of the most important differences in this context is the significant increase of water consumption in urban areas (Figure 1).

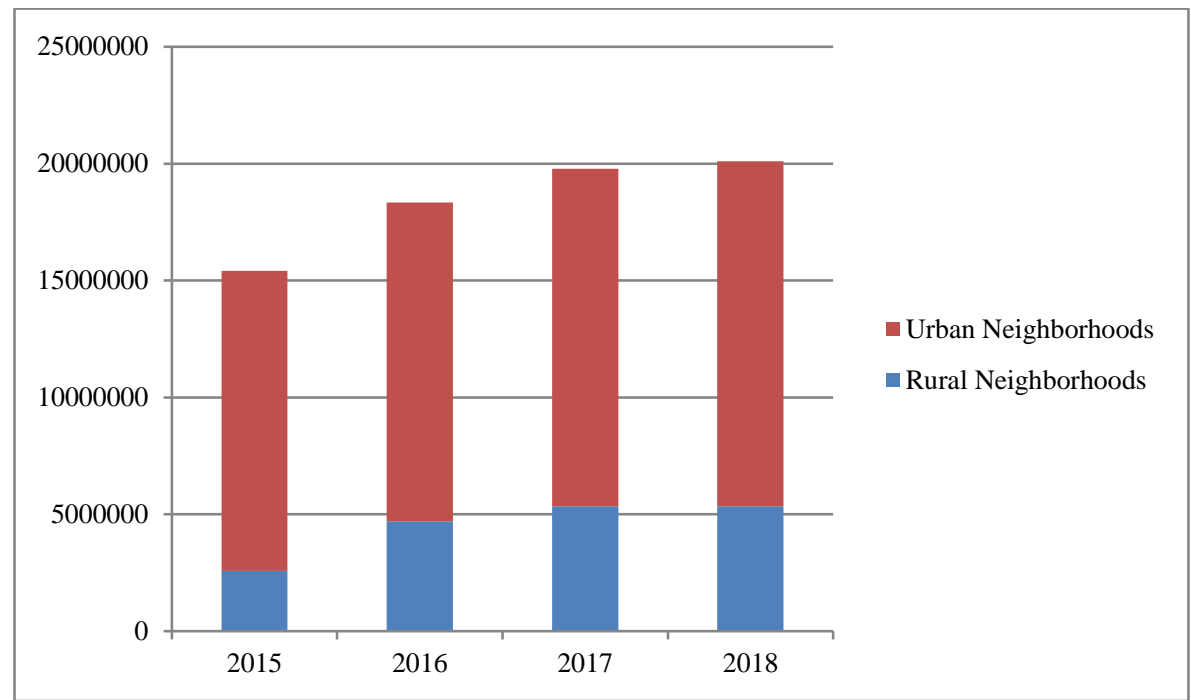

Figure 1. Water consumption in Balıkesir city (Altieylul and Karesi) according to rural and urban neighbourhoods

Source: Formed according to data obtained from Balıkesir Water and Sewerage Administration General Directorate

\section{Method}

The distribution of water consumption also varies among the neighbourhoods due to various factors. In this study, the correlation between certain variables (the population, the number of workplaces/commerce houses, the income level, education level) and the water consumption in the neighbourhoods of Balıkesir was examined with correlation analysis (SPSS 16.0).

Water consumption data for the years 2015, 2016, 2017 and 2018 in Balıkesir urban districts were obtained from Balıkesir Water and Sewerage Administration General Directorate. Water consumption data covers all subscriptions. The average of water consumption in the last 4 years in 40 urban districts of Bal1kesir was used for statistical measurements. 
For population, workplace/commercial workplaces, food aid and well water subscription 2018 data were used. 2018 population data by neighbourhood was obtained from Turkey Statistical Institute's official website. Workplace/commercial workplaces data and food aid data were obtained from Alt1eylül and Karesi municipalities, and well water subscription data were obtained from Balıkesir Water and Sewerage Administration General Directorate.

Since the income and education level data of the neighbourhoods are not available, the income level has been calculated by considering the ratio of food aid given to the neighbourhoods in 2018. As for the educational level the ratio of high school graduates to the total population of the neighbourhood was used from Aliğaoğlu (2007: 70-71). This statistical adjustment for both income and education level was produced solely for the purpose of making associations for this study. Distribution maps were created by editing and processing data to the neighbourhood map in ArcGis 10.0.

\section{Results}

First of all, the difference between the amount of water consumed in the years 2015 and 2018 was 2,007,948 $\mathrm{m}^{3}$ in 40 urban districts surveyed. According to the correlation analysis, there is a high level positive correlation between annual water consumption and population of the neighbourhoods $(\mathrm{r}=0.980)$. As the population of the neighbourhood increases, the total water consumption increases as well. There is a medium level significant and positive relation between the number of commercial workplaces and annual water consumption $(\mathrm{r}=0.365)$. Water consumption increases with the increase of the number of commercial workplaces, but their relationship is medium level. The number of commercial workplaces of the neighbourhoods and the amount of water consumption per person $\left(\mathrm{m}^{3}\right)$ there is a medium level significant and positive relationship ( $\mathrm{r}=0.558)$. Accordingly, the amount of water consumption per person increases with the increase of commercial workplaces in the neighbourhood. The relation between the increases of the number of commercial workplaces and the amount of water consumed per capita, is related to the increase of water consumption by commercial workplaces and the population (inhabited) decreases in these areas. There is a low level negative correlation $(r=-0.242)$ between water consumption per capita $\left(\mathrm{m}^{3}\right)$ and population. This shows that there are other parameters that must also be considered in this respect. For this reason, the correlation analysis examines the relationship between each parameter and water consumption, by controlling the effect of other parameters.

In the partial correlation analysis, when the workplace data is kept constant, there is still a high positive correlation between the population and annual water consumption $(\mathrm{r}=0.980)$. When population data is kept constant, there is a high level of significant relationship between commercial workplaces and annual water consumption ( $\mathrm{r}=698)$. When population data is kept constant, there is a middle level significant and positive relationship between water consumption of per person and the commercial workplaces ( $\mathrm{r}=0.653)$. When commercial workplaces data is kept constant, there is a middle level significant and negative relation between population and water consumption per person $(r=-0.464)$.

According to the results of the correlation analysis between water consumption and annual water use per person $\left(\mathrm{m}^{3}\right)$, commercial workplaces and population data, the most important variable effecting water consumption in neighbourhoods is the population. In addition, demographic variables such as the 
number of households, household size, average age of the population, income level and education level also affect water consumption.

There is a high level significant, positive relation between water consumption and the number of households in the examined neighbourhoods $(r=0.972)$. At this point, household size becomes importance but such data for neighbourhoods was not available. There is a middle level significant, positive relation between water consumption and educational level $(\mathrm{r}=0.397)$.

Since there is no income level data available for the investigated neighbourhoods, so this information was deducted from the food aid provided to the neighbourhoods. According to the correlation analysis, there is a middle level significant, positive correlation between food aid rate and water consumption ( $\mathrm{r}=0.572$ ). Accordingly, as food aid rate increases, in other words, as the income level decreases, water consumption increases.

Increasing income levels affect water consumption in different ways. On the one hand, using water consciously and on the other, living standards (spending time outside the home, using a dishwasher, provide some cleaning needs outside the home (dry cleaning, carpet washing, personal hygiene etc.) may reduce water consumption.

As the level of education increases, it is expected that water consumption will decrease as individuals become aware of the savings and sustainability of natural resources. However, this is not independent from other variables. In addition, local conditions such as water price, public fountains or well water subscription also affect water consumption.

The education level, income level etc. are important variables in terms of water consumption, but subjective values such as world view of the individual, view of nature, being conscious and their sensitivity level towards nature and natural resources are also very important. In this respect, this study reveals the geographical distribution of water consumption according to neighbourhoods and the level of some variables affecting water consumption. Individual variables in water consumption and the realities underlying it, however, appears to be topics to be considered in another study.

\section{Referanslar/References}

Akın, M., Akın, G. (2007). Suyun Önemi, Türkiye'de Su Potansiyeli, Su Havzaları ve Su Kirliliği, Ankara Üniversitesi Dil ve Tarih-Coğrafya Fakültesi Dergisi, 47 (2), 105-118.

Aksungur, N., Firidin, Ş. ve SUMEA. (2008). Su Kaynaklarının Tüketimi ve Sürdürülebilirlik, SUMEA Yunus Araştırma Bülteni, 8 (2), 9-11.

Aliağaoğlu, A. (2007). Balıkesir Şehrinde Suçlar: Coğrafi Bir Yaklaşım (2005). Detay Yayınları: Ankara.

Aslan, B., Önen, F., Hamdi, N. (2018). Diyarbakır Kentinin içme suyu ihtiyacının genetik ifadeli programlama ile modellenmesi, DÜMF Mühendislik Dergisi, 9 (2), 859-870.

Baldino, N., Sauri, D. (2018). Characterizing the recent decline of water consumption in Italian Cities, Investigations Geogaraficas, 6, 9-21.

Balıkesir Su ve Kanalizasyon İdaresi (2019) http://www.balikesir-baski.gov.tr/index.php?su_kaynaklari=0

Balıkesir Büyükşehir Belediyesi ve İlçe Belediyeler (Altıeylül, Karesi) (2018) Gıda yarımı verileri.

Büyüköztürk, Ş. (2019). Sosyal Bilimler İçin Veri Analizi El Kitabı. 25. Baskı. Pegem Akademi. Ankara.

Ceylan, İ. (2010). Binalarda Su Tasarrufu Yöntemleri, TTMD, 52-54.

Fan, L., Gai, L., Tong, Y., Li, R. (2017). Urban Water Consumption and its Influencing factors in China: Evidence from 286 
Cities, Journal of Cleaner Production, 166, 124-133.

Gezer, A., Ayça, E. (2018). Su Stresi, Su Kıtlığı ve Su Tasarrufu Hakkında Halkın Farkındalığının Belirlenmesi: Akdeniz Üniversitesi Örnek Çalışması, Doğal Afetler ve Çevre Dergisi, 4 (2), 113-122.

Karakuş, E. (2014). Bireylerin Su Tüketim Tercihlerine Etki Eden Faktörler: Edirne İli Örneği, Trakya Üniversitesi, Sosyal Bilimler Enstitüsü İşletme Anabilim Dalı Yüksek Lisans Tezi.

Kızılçaoğlu, A. (2002). Kille Çayı Havzasının (Balıkesir) Jeomorfolojisi ve Uygulamalı Jeomorfolojisi, İstanbul: İstanbul Üniversitesi Sosyal Bilimler Enstitüsü.

Koday, Z. ve Kaya, G. (2012). Erzurum Şehrinin Su İhtiyacının Karşılanmasında Palandöken Barajının Yeri ve Önemi. Atatürk Üniversitesi Sosyal Bilimler Enstitüsü Dergisi, 16 (2), 285-301.

Lins, G.M.L., Cruz, W, S., Vieira, Z., Neto, F. A.C., 4 and Érico A.A. Miranda, E.A.A. (2010). Determining indicators of Urban Household Water Consumption through Multivariate Statistical Technique, Journal of Urban and Environmental Engineering, 4, (2), 74-80.

Pehlivan, E., Mete, B., Bektaș, D., Bayat, S. ve Kart, A. (2017). Malatya İlinde Yaşayan Genç Yetişkinlerin Su Tüketim Davranışlarının Değerlendirilmesi, 2. Uluslararası Su ve Sağlık Kongresi, 131-142.

Susurluk Nehir Havzası Yönetim Planı (2018). Havza Koruma Eylem Planlarının Nehir Havzası Yönetim Planlarına Dönüştürülmesi İçin Teknik Yardım. Susurluk Nehir Havzası Yönetim Planı. Kasım 2018. http://ribamap.ormansu.gov.tr/shared/files/en_1546426384.pdf adresinden 09.07.2019 tarihinde erişilmiştir.

Praskievicz, S., Chang, H. (2007). Identifying the relationship Between Water Consumption and Weather Variables in Seoul, Korea, Physical Geography 30 (4), 324-337.

Tortajada, C. (2006). Water Management in Mexico City Metropolitan Area, Water Resources Development, 22 (2), 353-376.

Teksoy, A., Nalbur, B.E., Akal Sönmez, S.K. (2017). Assessement of Water and Waste Water Potantial of Bursa City, Uludă University Journal of the Faculty of Engineering, 22 (1), 115-123.

Türkiye Cumhuriyeti Çevre ve Şehircilik Bakanlığı (2019) Türkiye Çevre Sorunları ve Öncelikleri Değerlendirme Raporu (2017 y1li verileriyle). Yay no.43. Ankara. https://webdosya.csb.gov.tr/db/ced/icerikler/2017-cevre-sorunlari-ve-oncelkler--20190628084520.pdf adresinden 27.08.2019 tarihinde erişildi.

TÜİK (2016) Belediye Su İstatistikleri Türkiye ve Balıkesir 2016 verisi. Türkiye İstatistik Kurumu resmi web sitesi. www.tuik.gov.tr

Uğur, A., Aliağaoğlu, A. (2018). Şehir Coğrafyası, Nobel Yayınevi, Ankara.

United Nations Educational, Scientific and Cultural Organization (UNESCO). (2019). The United Nations World Water Development Report 2019: Leaving No One Behind. Paris. France. https://unesdoc.unesco.org/ark:/48223/pf0000367306 adresinden 28.08.2019 tarihinde erişildi.

Yoo, S. H. (2007). Urban Water Consumption and Regional Economic Growth: The Case of Taejeon-Korea, Water Resources Management, 21 (8), 1353-1361. 